\title{
PERANAN NOTARIS SEBAGAI SAKSI (SYÂHID) TERHADAP SUATU PERBUATAN MELAWAN HUKUM YANG DILAKUKAN PIHAK DALAM AKTA NOTARIS (STUDI PERKARA NOMOR 269/PID.B/2015/PN.PDG)
}

\author{
Dia Ikhsan \\ Universitas Andalas, diaikbsan98@gmail.com \\ Ismansyah \\ Universitas_Andalas, ismansyah_2006@yahoo.co.id
}

\begin{abstract}
Notary is one of the general officers authorized to create an authentic deed and other authorities as intended in the law. Notary can be called as a notary as a witness, suspect and accused in the event of an act against the law of the Outentic deed made in a notary public. The problem in this writing is 1) the role of notary as a witness against the deeds of the law committed by the parties in Notarial deed and 2) the judgment of judges in the verdict No. 269/Pid. B/2015/PN. PDG about the role of notary as a witness against the deeds of the law committed by the party in notarial deed. The research method used is a method of normative juridical approach empirical. The result of the study of notarial roles as witnesses of the Act against the law by the party in notarial deed came to fulfill the call as a witness in the interest of an investigation, a notary called for investigation Must be approved by the notary Honorary assembly and give information on what is provided by the Parties both oral and written in writing. Notary is called and needs his presence in the examination of criminal matters, in capacity as a general officer who makes authentic deed, it is necessary for his testimony of what is seen, heard and supporting evidence in the creation of authentic deeds The criminal matter, 2) the judgment of judges in the Decree No. 269/Pid. B/2015/PN. PDG about the role of notary as a witness against the deeds of the law conducted by the party in Notarial deed is a notary only as a witness called the court to be heard his description of the conduct of the law Done by the defendant is about the forgery of the SS signatures to make the letter of authorization selling and besides notary also called a witness from the notary party who is a witness in the making of the selling power deed.
\end{abstract}

Keywords: Notary, Witnesses and Deeds Against the Law.

\begin{abstract}
Abstrak
Notaris merupakan salah satu pejabat umum yang berwenang untuk membuat akta otentik dan kewenangan lainnya sebagaimana dimaksudkan dalam undang-undang. Notaris bisa yang dipanggil sebagai notaris sebagai saksi, tersangka dan terdakwa apabila terjadi perbuatan melawan bukum dari akta outentik yan dibuat duhadapan notaris.Permasalahan dalam penulisan ini adalab 1) Peranan notaris sebagai saksi terhadap perbuatan melawan bukum yang dilakukan oleh pibak dalam akta notaris dan 2)Pertimbangan hakim dalam Putusan Nomor 269/Pid.B/2015/PN.PDG mengenai Peranan notaris sebagai saksi terhadap perbuatan melawan bukum yang dilakukan oleh pibak dalam akta notaris. Metode penelitian yang digunakan adalab metode pendekatan yuridis normatif empiris. Hasil penelitian Peranan notaris sebagai saksi terbadap perbuatan melawan bukum yang dilakukan oleh pibak dalam akta notaris adalah datang memenubi panggilan sebagai saksi demi kepentingan penyidikan, notaris yang dipanggil untu kepentingan penyidikan haruslah mendapat persetujuan dari Majelis Kehormatan Notaris dan memberikan keterangan mengenai apa yang diberikan oleh para pihak baik lisan maupun tertulis dipersidangan. Notaris dipanggil dan perlu kehadirannya dalam pemeriksaan suatu perkara pidana, dalam kapasitasnya sebagai pejabat umum yang membuat akta otentik, maka diperlukan kesaksiannya terhadap apa yang dilihat, didengar dan bukti-bukti pendukung dalam pembuatan akta otentik tersebut, yang ternyata terindikasi suatu perkara pidana, 2) Pertimbangan bakim dalam putusan perkara nomor 269/Pid.B/2015/PN.PDG mengenai peranan notaris sebagai saksi terbadap perbuatan melawan bukum yang dilakukan oleb pibak dalam akta notaris adalah notaris hanya sebagai saksi yang dipanggil kepengadilan untuk didengar keterangannya terbadap perbuatan melwan bukum yang dilakukan oleh
\end{abstract}


terdakwa yaitu mengenai pemalsuan tandatangan SS untuk membuat surat kuasa menjual dan selain notaris juga dipanggil saksi dari pihak notaris yang merupakan saksi dalam pembuatan akta kuasa jual tersebut.

Kata Kunci: Notaris, Saksi dan Perbuatan Melawan Hukum.

\section{PENDAHULUAN}

Notaris merupakan salah satu pejabat umum yang berwenang untuk membuat akta otentik dan kewenangan lainnya sebagaimana dimaksudkan dalam undang-undang. Sebagaimana disebutkan dalam Pasal 1 ayat (1) Undang-Undang Nomor 2 Tahun 2014 tentang Perubahan Atas Undang-Undang Nomor 30 Tahun 2004 tentang Jabatan Notaris (untuk selanjutnya disebut juga UUJN) bahwa Notaris adalah pejabat umum yang berwenang untuk membuat akta autentik dan memiliki keewenangan lainnya sebagaimana dimaksud dalam Undang-Undang ini atau berdasarkan Undang-Undang lainnya.

Pemanggilan notaris sebagai saksi merupakan bentuk pertanggung jawaban apa yang telah notaris lakukan dalam pembuatan akta outentik. Pembuatan akta notaris dapat dijadikan alat pembuktian, apabila terjadi sengketa di antara para pihak, persengketaan tersebut tidak menutup kemungkinan melibatkan notaris, maka atas keterlibatan itu notaris harus ikut bertanggung jawab terhadap apa yang telah dilakukannya. Hakim memiliki wewenang sepenuhnya dan memutuskan terhadap adanya suatu sengketa, dan untuk itu hakim berhak menilai apa dan bagaimana akta yang menyangkut perkara. Notaris dapat dimintakan pertanggung jawaban terhadap tugasnya, karena hal ini merupakan sumpah yang diucapkan notaris sebelum menjalankan jabatannya. Yang tercantum di dalam Pasal 4 ayat (1) UUJN, menyatakan:

1. Sebelum seorang notaris melaksanakan jabatannya, terlebih dahulu wajib mengucapkan sumpah/janji menurut agamanya dihadapan Menteri atau Pejabat yang ditunjuk.

2. Sumpah sebagaimana dimaksud pada ayat (1) berbunyi sebagai berikut:
Saya bersumpah/berjanji :

Babwa saya akan patuh dan setia kepada Negara Republik Indonesia, Pancasila dan Undang-Undang Dasar Negara Republik Indonesia Tabun 1945, Undang-Undang tentang Jabatan Notaris serta peraturan perundang-undangan lainnya. Babwa saya akan menjalankan jabatan saya dengan amanah, jujur, seksama, mandiri, dan tidak berpibak.

Bahwa saya akan menjaga sikap, tingkah laku saya, dan akan menjalankan kewajiban saya sesuai dengan Kode Etik Profesi, kehormatan martabat, dan tanggung jawab saya sebagai notaris.

Babwa saya akan merahasiakan isi akta dan keterangan yang diperoleh dalam pelaksanaan jabatan saya.

Babwa saya untuk dapat diangkat dalam jabatan ini, baik secara langsung, dengan nama atau dalih apapun, tidak pernab dan tidak akan memberikan atau menjanjikan sesuatu kepada siapapun.

Dalam mempertanggung jawabkan terhadap akta yang dibuatnya, notaris dapat dipanggil untuk menghadiri sidang pada Pengadilan Negeri tetapi notaris juga harus merahasiakan terhadap akta yang dibuatnya sesuai dengan sumpah/janji jabatan kecuali undang-undang yang menentukan. Hal ini ditentukan dalam Undang Undang Jabatan Notaris, sebagai berikut :

1. Di dalam Pasal 16 ayat (1) huruf f UUJN, menyatakan bahwa dalam menjalankan jabatannya, notaris antara lain berkewajiban merahasiakan segala sesuatu mengenai akta yang dibuatnya dan segala keterangan yang diperoleh guna pembuatan akta sesuai dengan sumpah/janji jabatan, kecuali Undang-Undang menentukan lain.

2. Di dalam Pasal 54 UUJN, menyatakan bahwa Notaris hanya dapat memberikan, memperlihatkan, atau memberitahukan isi akta, grosse akta, salinan akta atau kutipan 
akta kepada orang yang berkepentingan langsung pada akta, ahli waris, atau orang yang memperoleh hak, kecuali ditentukan lain oleh peraturan perundang-undangan.

3. Selain diatur dalam UUJN mengenai merahasiakan akta yang dibuat oleh Notaris, maka diatur juga dalam Pasal 1909 ayat (2) huruf 3e KUHPerdata bahwa segala siapa yang karena kedudukannya, pekerjaannya atau jabatannya menurut Undang-Undang, diwajibkan merahasiakan sesuatu, namun hanyalah semata-mata mengenai hal-hal yang pengetahuannya dipercayakan kepadanya sebagai demikian.

Notaris wajib merahasiakan isi akta, tidak hanya apa yang dicantumkan dalam aktaaktanya, akan tetapi juga semua yang diberitahukan atau disampaikan kepadanya dalam kedudukannya sebagai notaris, sekalipun itu tidak dicantumkan dalam aktanya. Sebagai salah satu perangkat hukum, disatu sisi notaris mempunyai hak ingkar sebagai pejabat umum yang profesional, dengan harus memegang sumpah jabatannya untuk tidak memberitahukan isi aktanya, di sisi lain notaris harus berdiri pada kepentingan negara yang mengacu pada kepentingan publik guna terselesainya proses hukum dalam peradilan, sehingga menghasilkan suatu putusan yang adil, bermanfaat dan menjamin kepastian hukum. Dengan adanya suatu amanah yang diberikan kepada seorang notaris, tanggung jawab notaris terhadap suatu akta tidak hanya menyangkut kepentingan pribadi, tetapi juga menyangkut kepentingan umum.

Dalam proses pemanggilan notaris sebagai saksi penyidk harus memperoleh persetujuan dari Majelis Kehormatan Notaris (MKN) yang diatur di dalam Pasal 66 UUJN , menyatakan:

1. Untuk kepentingan proses peradilan, penyidik, penuntut umum, atau hakim dengan persetujuan majelis kehormatan notaris berwenang: a. Mengambil fotokopi minuta akta dan/atau surat-surat yang dilekatkan pada minuta akta atau protokol notaris dalam penyimpanan notaris; dan

b. Memanggil notaris untuk hadir dalam pemeriksaan yang berkaitan dengan akta atau protokol notaris yang berada dalam penyimpanan notaris.

2. Pengambilan fotokopi minuta akta atau surat-surat sebagaimana dimaksud pada ayat (1) huruf a, dibuat berita acara penyerahan.

3. Majelis kehormatan notaris dalam waktu paling lama 30 (tiga puluh) hari kerja terhitung sejak diterimanya surat permintaan persetujuan sebagaimana dimaksud pada ayat (1) wajib memberikan jawaban menerima atau menolak permintaan persetujuan.

4. Dalam hal majelis kehormatan notaris tidak memberikan jawaban dalam jangka waktu sebagaimana dimaksud pada ayat (3), majelis kehormatan notaris dianggap menerima permintaan persetujuan.

Dalam pemanggilan notaris sebagai saksi karena merupakan pejabat yang mempunyai kewenangan dalam membuat akta outentik ini juga terjadi di kota padang dalam perkara Nomor 269/Pid.B/2015/PN.PDG. Perkara ini diajukan karena terdakwa telah terbukti melakukan tindak pidana dengan sengaja memakai surat palsu atau yang dipalsukan seolah-olah sejati (asli), jika pemakaian surat itu dapat menimbulkan kerugian sebagaimana di atur dan diancam dalam dakwaan kedua Penuntut Umum yakni di dalam pasal 263 ayat (2) KUHP .

Terdakwa telah membuat surat kuasa menjual dengan Nomor 34 tanggal 9 November 2010 bertempat di kantor Notaris EP. Di mana dasar pembuatan surat kuasa menjual tersebut adalah surat ranji tanggal 21 Oktober 2010 dan surat keterangan ahli waris tanggal 22 Oktober 2010. Dari Pihak (sebut saja SS) dengan uraian kasus bahwa pada 
tanggal 09 Nopember 2010, SS datang kekantor Notaris SS untuk membuat Surat Kuasa Jual. SRS sebagai saksi dan Mamak kepala waris Kaum Jurai adalah pemegang kekuasaan terhadap sertifikat tanah HM Nomor 777 GS bertempat di Jalan Padang By Pass. Di mana dasar pembuatan surat kuasa menjual tersebut adalah surat ranji tanggal 21 Oktober 2010 dan surat keterangan ahli waris tanggal 22 Oktober 2010. Namun dalam surat ranji, surat keterangan waris serta surat kuasa menjual tersebut tanda tangan saksi SRS diakui oleh saksi bukan tanda tangan saksi karena saksi tidak pernah membuat surat ranji dan surat keterangan waris yang baru sedangkan saksi juga tidak pernah datang ke kantor Notaris EP tersebut dan tidak pernah ikut menandatangani surat kuasa menjual tersebut.

Bahwa didalam warkah sertifikat dimaksud ditemukan perbedaan tanda tangan saksi SRS pada surat keterangan ahli waris, Ranji kaum dan surat kuasa menjual. Selain tanda tangan SRS juga ditemukan perbedaan tanda tangan saksi $\mathrm{H}$ di dalam surat keterangan ahli waris tanggal 22 Oktober 2010, dimana berdasarkan keterangan saksi SRS kaum almarhumah JS belum pernah membuat surat keterangan ahli waris dan berdasarkan keterangan saksi kaumnya sudah ada mempunyai Silsilah Ranji Kaum Puti Suku Jamabak Nan Batujuah Kel. Sungai Sapih Kenagarian Pauh IX Kec. Kuranji Kota Padang. Berdasarkan Surat Keputusan Kaum No. 001/ HW-1/1087774 tanggal 12 April 1987 dan rapat Keputusan Kaum Jurai Almarhumah Suma tanggal 19 Maret 1995. Berdasarkan keterangan saksi SRS dan saksi $\mathrm{H}$ serta saksi $\mathrm{S}$ yang bersangkutan tidak pernah menandatangani surat keterangan ahli waris yang dibuat oleh terdakwa SS.

Tanah didalam sertifikat tersebut sudah terjual pada pihak lain dengan menggunakan surat kuasa untuk menjual yang mana surat kuasa menjual tersebut yang dibuat di kantor Notaris EP selanjutnya setelah dilakukan pengecekan di kantor Notaris tersebut terhadap surat kuasa menjual, ternyata pada surat kuasa menjual tersebut terdapat perbedaan tanda tangan saksi SRS dan tanda tangan saksi $\mathrm{H}$ pada surat keterangan ahli waris dan surat Kuasa menjual tersebut.

Setelah dilakukan pengecekan di kantor Notaris tersebut terhadap surat kuasa menjual, ternyata pada surat kuasa menjual tersebut terdapat juga perbedaan tanda tangan saksi SRS dikarenakan karena adanya perbedaan tanda tangan saksi SRS dan tanda tangan saksi $\mathrm{H}$ pada surat keterangan ahli waris dan surat Kuasa menjual tersebut.

Berdasarkan uraian kasus di atas maka notaris bertanggungjawab terhadap akta kuasa jual yang telah dibuat dikantornya. Jabatan notaris merupakan jabatan kepercayaan antara para pihak dengan notarisnya sendiri. Jika salah satu melakukan hal yang tidak sesuai dengan peraturan perUndang-Undangan maka harus dibuktikan oleh pihak yang menyangkalnya. Kinerja notaris ditentukan oleh nilai kejujuran. Dengan kata lain, hubungan notaris dan klien membutuhkan adanya kejujuran dan kepercayaan. Nilai kejujuran klien merupakan nilai yang paling mendasar dalam mendukung keberhasilan kinerja notaris dalam pembuatan akta yang dipercayakan kepadanya begitupun sebaliknya.

Notaris sebagai pejabat umum memiliki hak-hak istimewa. Hak-hak tersebut berkaitan dengan hak ingkar notaris, perlakuan dalam hal pemanggilan, pemeriksaan, proses penyelidikan dan penyidikan. Dalam hal pemeriksaan notaris, sebelum adanya Putusan Mahkamah Konstitusi Nomor 49/PUUX/2013 tanggal 2 Maret 2013 pemeriksaaan proses hukum yang melibatkan notaris memerlukan persetujuan Majelis Pengawas Daerah (MPD). Menurut Habib Adjie:

"Berdasarkan putusan MK itu, terhadap proses peradilan penyidik, penuntut umum, atau hakim yang berwenang untuk mengambil fotokopi minuta akta atau protokol notaris 
dalam penyimpanan, serta memnaggil Notaris untuk hadir dalam pemeriksaan yang berkaitan dengan akta yang dibuatnya atau protokol notaris yang berada dalam penyimpanan notaris tanpa persetujuan MPD."1

Meskipun dengan adanya Putusan Mahkamah Konstitusi Nomor 49/PUU$\mathrm{X} / 2013$ yang menyatakan bahwa pemeriksaan notaris tidak memerlukan persetujuan MPD, dalam hal ini notaris mempunyai kewajiban ingkar bukan untuk kepentingan diri notaris tapi untuk kepentingan para pihak yang telah mempercayakan kepada notaris. ${ }^{2}$

Notaris wajib merahasiakan segala sesuatu yang ia ketahui sehubungan dengan pembuatan akta, yang dimintakan oleh pihakpihak, demikian juga untuk hal-hal lain yang ada kaitannya dengan pembuatan akta tersebut. Hal ini sangat penting, karena notaris harus melindungi kepentingan para pihak yang ada hubungannya dengan akta tersebut. Jabatan notaris adalah jabatan kepercayaan yang dengan sendirinya melahirkan suatu kewajiban untuk merahasiakan segala sesuatu yang dipercayakan oleh pihak-pihak kepadanya, kecuali undang-undang memerintahkannya untuk membuka rahasia dan memberikan keterangannya/pernyataan tersebut kepada pihak yang memintanya. ${ }^{3}$

Tulisan ini memfokuskan pembahasan tentang bagaimana peranan notaris sebagai saksi terhadap perbuatan melawan hukum yang dilakukan oleh pihak dalam akta notaris. Selain itu tulisan ini juga mengkaji apakah

\footnotetext{
1 Habib Adjie, Kajian Putusan Mabkamah Konstitusi Terbadap Pasal 66 Ayat 1 UUJN,http://habibadjie.dosen.narotama.ac.id/files/20 13/07/Kajian-Putusan-MK-Pasal-66-UUJN.pdf, diakses pada tanggal 6 maret 2018

2 Syafran Sofyan, Putusan Mabkamah Konstitusi Nomor 49/PUU-X/2013 dan Sikap Notaris, http://www.jimlyschool.com/read/analisis/378/putusa n-mahkamah-konstitusi-nomor-49puux2013-dan-sikapnotaris-oleh-syafran-sofyan/, diakses pada tanggal 6 maret 2018.

3 Habib Adjie, Menjalin Pemikiran-Pendapat Tentang Kenotariatan, (Bandung: Citra Aditya Bakti, 2013), 99.
}

pertimbangan hakim dalam Putusan Nomor 269/Pid.B/2015/PN.PDG mengenai peranan notaris sebagai saksi terhadap perbuatan melawan hukum yang dilakukan oleh pihak dalam akta notaris.

Metode Penelitian yang digunakan dalam penelitian ini adalah Yuridis Empiris degan pendekatan Studi Kasus seperti yang dijelaskan di atas. ${ }^{4}$ Studi kasus ini dijabarkan dengan pendekatan kualitatif dengan wawancara dan patisipasi. ${ }^{5}$

\section{TINJAUAN TEORI: NOTARIS}

Notaris adalah pejabat umum yang berwenang untuk membuat akta otentik dan memiliki kewenangan lainnnya sebagaimana dimaksud dalam Pasal 1 angka 1 UUJN. Pasal 1 Peraturan Jabatan Notaris merumuskan pengertian notaris bahwa Notaris adalah pejabat umum yang satu-satunya berwenang untuk membuat akta otentik mengenai semua perbuatan, perjanjian, dan penetapan yang diharuskan oleh suatu peraturan umum atau oleh yang berkepentingan dikhendaki untuk dinyatakan dalam suatu akta otentik, menjamin kepastian tanggalnya, menyimpan aktanya, memberikan grosse, salinan dan kutipannya, semuanya sepanjang pembuatan akta itu oleh peraturan umum tidak ditugaskan atau dikecualikan kepada pejabat atau orang lain.

Kedudukan notaris sebagai Pejabat Umum dalam arti kewenangan yang ada pada notaris tidak pernah diberikan kepada pejabat lainnya, selama sepanjang kewenangan tersebut tidak menjadi kewenangan pejabatpejabat lain dalam membuat akta otentik dan kewenangan lainnya maka kewenangan tersebut menjadi kewenangan notaris. ${ }^{6}$ Pengertian notaris sebagai pejabat umum satusatunya yang berwenang membuat akta dalam

4 Soerjono Soekanto dan Sri Mamudji, Penelitian Hukum Normatif, (Jakarta: Raja Grafindo Persada), 22.

5 Soerjono Soekanto, Pengantar Penelitian Hukum, (Jakarta: UI-Press), 2007, 10.

${ }^{6}$ Habib Adjie, Menjalin Pemikiran..., 40. 
rumusan PJN tidak lagi digunakan dalam UUJN. Penggunaan kata satu-satunya (uitsluitend) dimaksudkan untuk memberi penegasan bahwa notaris adalah satu-satunya yang mempunyai wewenang umum untuk itu, tidak turut pejabat lainnya.

Dengan demikian notaris merupakan suatu jabatan (publik) yang mempunyai karakteristik, yaitu: ${ }^{7}$

Sebagai jabatan. UUJN merupakan unifikasi di bidang pengaturan jabatan notaris, artinya satu-satunya aturan hukum dalam bentuk undang-undang yang mengatur jabatan notaris di Indonesia, sehingga segala hal yang berkaitan notaris di Indonesia harus mengacu kepada UUJN. Jabatan notaris merupakan suatu lembaga yang diciptakan oleh negara. Menempatkan notaris sebagai jabatan merupakan suatu bidang pekerjaan atau tugas yang sengaja dibuat oleh aturan hukum untuk keperluan dan fungsi tertentu (kewenangan tertentu) serta bersifat berkesinambungan sebagai suatu lingkungan pekerjaan yang tetap.

Notaris mempunyai kewenangan tertentu. Setiap wewenang yang diberikan kepada jabatan harus ada aturan hukumnya, sebagai batasan agar jabatan dapat berjalan dengan baik dan tidak bertabrakan dengan wewenang jabatan lainnya. Dengan demikian jika seorang pejabat (notaris) melakukan suatu tindakan diluar wewenang yang telah ditentukan, dapat dikategorikan sebagai perbuatan melanggar wewenang notaris. Wewenang notaris hanya dicantumkan dalam Pasal 15 ayat (1), (2), dan (3) UUJN.

Diangkat dan diberhentikan oleh pemerintah. Pasal 2 UUJN menentukan bahwa notaris diangkat dan diberhentikan oleh pemerintah, dalam hal ini menteri yang membidangi kenotariatan (Pasal 1 angka 14 UUJN). Notaris meskipun secara administratif diangkat dan diberhentikan oleh pemerintah, tidak berarti notaris menjadi subordinasi (bawahan) yang mengangkatnya pemerintah. Dengan demikian

${ }^{7}$ Ibid, 15. karakteristik notaris dalam menjalankan tugas jabatannya adalah bersifat mandiri (autonomous), tidak memihak siapa pun (impartia), dan tidak bergantung kepada siapapun (independent), yang berarti dalam menjalankan tugas jabatannya tidak dapat dicampuri oleh pihak yang mengangkatnya atau oleh pihak lain.

Tidak menerima gaji atau pensiun dari yang mengangkatnya. Notaris meskipun diangkat dan diberhentikan oleh pemerintah tapi tidak menerima gaji, pensiun dari pemerintah. Notaris hanya menerima honorarium dari masyarakat yang telah dilayaninya atau dapat memberikan pelayanan cuma-cuma untuk mereka yang tidak mampu.

Akuntabilitas atas pekerjaannya kepada
masyarakat. Kehadiran Notaris untuk
memenuhi kebutuhan masyarakat yang memerlukan dokumen hukum (akta) otentik dalam bidang hukum perdata, sehingga notaris mempunyai tanggung jawab untuk melayani masyarakat, masyarakat dapat menggugat secara perdata notaris, dan menuntut biaya, ganti rugi dan bunga jika ternyata akta tersebut dapat dibuktikan dibuat tidak sesuai dengan aturan hukum yang berlaku.

Di samping itu, notaris juga mempunyai hak untuk mengundurkan diri apabila diminta untuk menjadi saksi. Dalam pembuatan akta terkadang terdapat masalah yang mungkin terjadi dan menimbulkan sengketa hukum, hal ini tidak bisa dihindari sekalipun notaris telah berhati-hati. Notaris akan dipanggil sebagai saksi yang diharapkan dapat menjadi titik terang atas sengketa hukum yang terjadi, akan tetapi notaris sendiri mempunyai rahasia jabatan yang harus dijaga dengan pengenaan sanksi apabila melakukan pelanggaran. Apabila terjadi demikian, notaris dapat menggunakan haknya untuk mengundurkan diri atau verschoningsrecht. Hak tersebut dapat digunakan jika notaris dimintai keterangan oleh pejabat penyidik (polisi, jaksa, hakim) dan /atau diminta menjadi saksi di muka pengadilan. Sayangnya hak ini belum atau tidak secara 
tegas dinyatakan dalam undang-undang Jabatan Notaris.

Sedangkan kewajiban Notaris diatur dalam Pasal 16 Undang-Undang Nomor 2 Tahun 2014 Tentang Perubahan Atas UndangUndang Nomor 30 Tahun 2004 Tentang Jabatan Notaris.

Dalam menjalankan jabatannya, Notaris wajib:

1. Bertindak amanah, jujur, saksama, mandiri, tidak berpihak, dan menjaga kepentingan pihak yang terkait dalam perbuatan hukum;

2. Membuat akta dalam bentuk minuta akta dan menyimpannya sebagai bagian dari protokol notaris;

3. Melekatkan surat dan dokumen serta sidik jari penghadap pada minuta akta;

4. Mengeluarkan grosse akta, salinan akta, atau kutipan akta berdasarkan minuta akta;

5. Memberikan pelayanan sesuai dengan ketentuan dalam undang-undang ini, kecuali ada alasan untuk menolaknya;

6. Merahasiakan segala sesuatu mengenai akta yang dibuatnya dan segala keterangan yang diperoleh guna pembuatan akta sesuai dengan sumpah/janji jabatan, kecuali undang-undang menentukan lain;

7. Menjilid akta yang dibuatnya dalam 1 (satu) bulan menjadi buku yang memuat tidak lebih dari 50 (lima puluh) akta, dan jika jumlah akta tidak dapat dimuat dalam satu buku, akta tersebut dapat dijilid menjadi lebih dari satu buku, dan mencatat jumlah minuta akta, bulan, dan tahun pembuatannya pada sampul setiap buku;

8. Membuat daftar dari akta protes terhadap tidak dibayar atau tidak diterimanya surat berharga;

9. Membuat daftar akta yang berkenaan dengan wasiat menurut urutan waktu pembuatan akta setiap bulan;

10. Mengirimkan daftar akta sebagaimana dimaksud dalam poin 9 atau daftar nihil yang berkenaan dengan wasiat ke pusat daftar wasiat pada kementerian yang menyelenggarakan urusan pemerintahan di bidang hukum dalam waktu 5 (lima) hari pada minggu pertama setiap bulan berikutnya;

11. Mencatat dalam repertorium tanggal pengiriman daftar wasiat pada setiap akhir bulan;

12. Mempunyai cap atau stempel yang memuat lambang negara republik indonesia dan pada ruang yang melingkarinya dituliskan nama, jabatan, dan tempat kedudukan yang bersangkutan;

13.Membacakan akta di hadapan penghadap dengan dihadiri oleh paling sedikit 2 (dua) orang saksi, atau 4 (empat) orang saksi khusus untuk pembuatan akta wasiat di bawah tangan, dan ditandatangani pada saat itu juga oleh penghadap, saksi, dan notaris; dan

14.Menerima magang calon Notaris.

\section{MENJADI SAKSI DALAM ISLAM}

Dalam khazanah literasi Islam, khususnya dalam narasi Alquran, terdapat beberapa perintah untuk menjadi manusia yang adil dan ketika bersaksi atau memutuskan perkara senantiasa atas nama Allah.

Tidak ada subyek narasi spesisfik yang menjelaskan kriteria sebagai Hakim, Pengacara, dan Saksi. Ajaran umum yang dijelaskan adalah perintah untuk berbuat adil dan bersaksi di setiap kasus dan situasi untuk selalu melakukan persaksian atas nama Allah.

Seperti yang tertulis dalam QS. AlNisa' ayat 135;

"Wahai orang-orang yang beriman, jadilah kamu orang yang benar-benar penegak keadilan, menjadi saksi karena Allah biarpun terhadap dirimu sendiri atau ibu bapa dan kaum kerabatmu. Jika ia kaya ataupun miskin, maka Allab lebih tabu kemaslahatannya. Maka janganlah kamu mengikuti hawa nafsu karena ingin menyimpang dari kebenaran. Dan jika kamu memutar balikekan (kata-kata) atau enggan menjadi saksi, maka sesunggubnya 
Allah adalab Maha Mengetabui segala apa yang kamu kerjakan."

Pada ayat tersebut, dijelaskan secara detil bagaimana seharusnya seorang manusia khsusunya Muslim untuk dapat menjadi saksi dengan adil dan bertanggung jawab atas apa yang dipersaksikannya kepada Allah. Selain itu, berbuat adil dan jujur dalam persaksian harus dimulai dari aspek psikologis diri sendiri untuk kemudian dapat berani mengambil keputusan tanpa memihak secara subyektif, baik kepada keluarga, kerabat, penguasa, hingga rakyat miskin biasa.

Begitupun ketika menjadi Notaris yang notaben telah diambil sumpahnya untuk selalu berkata, menulis, dan bertindak dengan jujur dan adil. Hendaknya, setiap notaris selalu melandasi pekerjaannya dan keputusannya tidak hanya karena tanggung jawab profesional, tetapi lebih dari itu, tanggung jawab spiritual juga diutamakan.

\section{PERANAN NOTARIS SEBAGAI SAKSI TERHADAP PERBUATAN MELAWAN HUKUM YANG DILAKUKAN OLEH PIHAK DALAM AKTA NOTARIS.}

Berdasarkan uraian di atas notaris dipanggil sebagai saksi apabila terjadi sengketa atau perbuatan melawan hukum yang dilakukan oleh para pihak mempunyai peranan.

Notaris datang memenuhi panggilan sebagai saksi demi kepentingan penyidikan. Notaris yang dipanggil untu kepentingan penyidikan haruslah mendapat persetujuan dari Majelis Kehormatan Notaris.

Notaris memberikan keterangan mengenai apa yang diberikan oleh para pihak baik lisan maupun tertulis dipersidangan. Keterangan notaris ini akan dipergunakan untuk kepentingan pembuktian agar hakim dapat memberikan pertimbangan yang sebaikbaiknya dalam memeriksa dan memutus sengketa antara para pihak.
Notaris yang dipanggil sebagai saksi ketika terjadi perbuatan melawan hukum yang berkaitan dengan akta yang dibuatnya. Sebagai pejabat umum, notaris memiliki keistimewaan atau privileged dalam proses pemeriksaan perkara pidana untuk melindungi kedudukannya. Oleh karenanya, terdapat ketentuan yang harus dipenuhi terlebih dahulu oleh penegak hukum, sebelum melakukan pemanggilan terhadap notaris. Hal tersebut sebagaimana diatur dalam Pasal 66 UUJN yaitu:

a. Jika diperlukan penegak hukum dalam proses peradilan yaitu penyidik, penuntut umum atau hakim dapat mengajukan surat permintaan persetujuan dalam rangka melakukan pemanggilan kepada seorang notaris. Surat tersebut diajukan ke Majelis Kehormatan Notaris.

b. Dalam kurun waktu paling lama 30 hari kerja terhitung sejak diterimanya surat permintaan tersebut, Majelis Kehormatan Notaris wajib memberikan jawabannya;

c. Jika dalam kurun waktu yang ditentukan Majelis Kehormatan Notaris tidak memberikan jawabannya, maka sikap diam Majelis Kehormatan Notaris dianggap telah menerima permintaan persetujuan tersebut. Sehingga penegak hukum dapat melakukan pemanggilan kepada notaris yang bersangkutan.

d. Setelah memperoleh persetujuan dari Majelis Kehormatan Notaris, penegak hukum berwenang untuk:

1) Meminta dan mengambil fotokopi dari minuta akta dan/atau surat-surat yang telah dilekatkan pada minuta akta dalam penyimpanan notaris (protokol notaris);

2) Sehubungan dengan pengambilan fotokopi dokumen-dokumen tersebut, penyidik akan membuatkan berita acara penyerahan untuk diserahkan kepada notaris tersebut. 
3) Memanggil notaris untuk hadir dalam proses pemeriksaan pidana yang berkaitan dengan akta atau protokol notaris yang berada dalam penyimpanannya.

Peranan notaris sebagai saksi apabila terjadi perbuatan melawan hukum terhadap akta yang dibuat dihadapan notaris sesuai dengan asas sistimatika hukum dan asas sinkronisasi hukum. Asas sistematika ini merupakan peneelitian yang dilakukan terhadap peraturan perundang-undangan. Dalam penulisan ini pemanggilan notaris sebagai saksi ini juga wajib untuk merahasiakan tidak hanya isi akta namun juga keterangan yang diperoleh untuk pembuatan akta yang dimuat dalam sumpah jabatan dan kode etik. Apabila notaris diminta untuk menjadi saksi tentang akta yang dibuat di hadapannya, notaris dilarang untuk membuka isi akta yang berarti telah membuka rahasia dengan ancaman pidana. Notaris cukup mengatakan bahwa akta yang dijadikan bukti itu betul memang dibuat di hadapan notaris tersebut.

\section{PERTIMBANGAN HAKIM DALAM PUTUSAN NOMOR 269/PID.B/2015/PN.PDG MENGENAI PERANAN NOTARIS SEBAGAI SAKSI TERHADAP PERBUATAN MELAWAN HUKUM YANG DILAKUKAN OLEH PIHAK DALAM AKTA NOTARIS.}

Dalam

269/Pid.B/2015/PN.PDG, pertimbangan hakim mengenai peranan notaris sebagai saksi terhadap perbuatan melawan hukum yang dilakukan oleh pihak dalam akta notaris adalah:

Notaris hanya sebagai saksi yang dipanggil kepengadilan untuk didengar keterangannya terhadap perbuatan melwan hukum yang dilakukan oleh terdakwa yaitu mengenai pemalsuan tandatangan SS untuk membuat surat kuasa menjual.
Dalam praktek tidak mungkin dihindari adanya notaris-notaris yang dipanggil menjadi saksi untuk memberikan keterangan tentang akta yang dibuatnya di muka persidangan bahkan ada pula notaris yang dipaksa untuk memberikan keterangan di hadapan penyidik untuk melancarkan penyidikan. Notaris sebagai pejabat yang menjalankan profesi dalam pelayanan hukum kepada masyarakat, perlu mendapatkan perlindungan dan jaminan demi tercapainya kepastian hukum.

Dalam pelaksanaan penandatangan akta kuasa jual yang dibuat dan ditandatangani dihadapan notaris ES ini memang ada perbedaan tandatangan dan notaris menanyakan tetapi dijawab oleh yang mengaku dirinya SS namanya juga orang sudah pensiun.

Selain notaris juga dipanggil saksi dari pihak notaris yang merupakan saksi dalam pembuatan akta kuasa jual tersebut

Berdasarkan uraian diatas Penelitian terhadap sinkronisasi hukum dalam hubungan vertikal dalam penulisan ini, dimana Pasal 263 ayat (1) dan (2) KUHP berlaku untuk SSY, karena perbuatan yang SSY lakukan bertentangan dengan hukum sehingga berlakunya ketentuan pasal tersebut. Menurut Majelis Hakim dengan segala pertimbangan yang akan dijelskan pada pembahasan tesisi ini, SSY akan dijatuhkan pada diri Terdakwa sebagaimana tercantum dalam amar putusan dibawah ini dipandang telah adil dan setimpal dengan kesalahan Terdakwa, serta dapat memiliki efek jera bagi Terdakwa sekaligus menjadi pelajaran atau peringatan bagi masyarakat pada umumnya .

Perbuatan melawan hukum yang dilakukan oleh terdakwa SSY selaian itu juga sesejalan dengan asas sistematika hukum. Karena perbuatan yang dilakukan terdakwa memenuhi unsru Pasal 263 KUHP yaitu dengan melakukan tindakan pidana pemalsuan tandatangan dari saksi SS. 
Tindakan terdakwa SSY ini telah memenuhi unsur-unsur dari tindak pidana yang diatur dalam pasal 263 ayat (2) KUHP dengan unsur "Barang Siapa". Unsur barangsiapa adalah menunjuk kepada manusia sebagai subyek hukum yang merupakan pendukung hak dan kewajiban, baik laki-laki atau perempuan yang mampu bertanggungjawab (toerekeningsvatbaar person) atas setiap tindakan atau perbuatan-perbuatan (materiale daden) yang dilakukannya.

Selain itu, unsur "Dengan Sengaja" dengan bunyi "memakai surat palsu atau yang dipalsukan seolab-olah sejati, jika pemakaian surat itu dapat menimbulkan kerugian" mengandung makna seseorang melakukan perbuatannya telah menghendaki perbuatannya dan menurut terminal hukum pidana pengertian "Perbuatan Membuat Surat Palsu" yang dimaksud dalam KUHP adalah Surat yang sebelumnya tidak ada atau belum ada yang sebagian atau seluruh isinya palsu dan surat yang dihasilkan dari perbuatan ini di sebut dengan "Surat Palsu".

\section{KESIMPULAN}

Peranan notaris sebagai saksi terhadap perbuatan melawan hukum yang dilakukan oleh pihak dalam akta notaris adalah datang memenuhi panggilan sebagai saksi demi kepentingan penyidikan, notaris yang dipanggil untu kepentingan penyidikan haruslah mendapat persetujuan dari Majelis Kehormatan Notaris dan memberikan keterangan mengenai apa yang diberikan oleh para pihak baik lisan maupun tertulis dipersidangan. Notaris dipanggil dan perlu kehadirannya dalam pemeriksaan perkara pidana, dalam kapasitas sebagai pejabat umum yang membuat akta otentik, diperlukan kesaksiannya terhadap apa yang dilihat, didengar dan bukti-bukti pendukung dalam pembuatan akta otentik tersebut, yang ternyata terindikasi perkara pidana.

Pertimbangan hakim dalam Putusan Nomor 269/Pid.B/2015/PN.PDG mengenai Peranan notaris sebagai saksi terhadap perbuatan melawan hukum yang dilakukan oleh pihak dalam akta notaris adalah notaris hanya sebagai saksi yang dipanggil kepengadilan untuk didengar keterangannya terhadap perbuatan melwan hukum yang dilakukan oleh terdakwa yaitu mengenai pemalsuan tandatangan SS untuk membuat surat kuasa menjual dan selain notaris juga dipanggil saksi dari pihak notaris yang merupakan saksi dalam pembuatan akta kuasa jual tersebut.

Sebagai saran, hendaknya notaris dalam melakukan tugas dan wewenang seharusnya telah mengetahui ada perbedaan tandatangan dan yang mana notaris tersebut telah mengetahui dari awal oleh karena itu notaris membuatkan Berita Acara Perbedaannya (BAP) tandatangannya. 


\section{DAFTAR KEPUSTAKAAN}

Habib, Adjie, Kajian Putusan Mabkamah Konstitusi Terbadap Pasal 66 Ayat 1 UUJN,http://habibadjie.dosen.narotama.ac.id/files/2013/07/Kajian-Putusan-MKPasal-66-UUJN.pdf, diakses pada tanggal 6 maret 2018 Menjalin Pemikiran-Pendapat Tentang Kenotariatan, Citra Aditya Bakti, Bandung, 2013.

Syafran, Sofyan, Putusan Mahkamah Konstitusi Nomor 49/PUU-X/2013 dan Sikap Notaris, http:// www.jimlyschool.com/ read/analisis/378/putusan-mabkamah-konstitusi-nomor49puих2013-dan-sikap-notaris-oleh-syafran-sofyan/, diakses pada tanggal 6 maret 2018.

Soekanto, Soerjono dan Sri Mamudji, Penelitian Hukum Normatif, Jakarta: Raja Grafindo Persada.

Soekanto, Soerjono, Pengantar Penelitian Hukum, Jakarta: UI-Press, 2007.

\section{BIBILIOGRAFI}

Kitab Undang-Undang Hukum Perdata (KUHPer)

Kitab Undang-Undang Hukum Acara Pidana (KUHAP)

Undang-Undang Nomor 2 Tahun 2014 tentang Perubahan Undang-Undang Nomor 30 Tahun 2004 tentang Jabatan Notaris 